\title{
The development of a STEM-based e-module to help fifth-grade pupils strengthen their creative thinking skills in the topic of My Blood Circulation
}

\author{
Desak Ketut Rani Astiti Asih ${ }^{1^{*}}$ \\ Sunyono ${ }^{2}$ \\ Dwi Yulianti ${ }^{3}$ \\ ${ }^{1,2,3}$ Postgraduate Program, University of Lampung, Bandar Lampung, Indonesia
}

\begin{abstract}
Technology and education are now required for the development of $21^{\text {st }}$ century skills. The purpose of this study was to determine 1) the practicality of STEAM-based e-Modules in online learning, 2) the importance of STEAM-based e-Modules in online learning, and 3) the improvement of students' creative thinking skills in fifth grade on the content "My Blood Circulation is Healthy." A total of 16 students were employed in the study. Questionnaires and tests were utilized as data gathering instruments. Problem and need analysis, literature review, product design, validation, and practitioner testing were the stages of development. The findings revealed that pupils' low creative thinking abilities were attributed to teachers' failure to adequately embrace technology and their continued usage of traditional instructional materials. The STEAM-based e-Module development improved creative thinking skills of Grade 5 students.
\end{abstract}

\section{KEYWORDS}

e-Modul; STEM; Creative

Thinking

Received: 2 August 2021

Accepted: 14 August 2021

Published: 20 August 2021

\section{Introduction}

The era of digitalization is a big challenge in all aspects of life. The development of technology brings industry 4.0 in learning. Learning activities are a major part of education in schools. Efforts to increase student interest in the learning process require updates regarding the learning resources that used. Technology and pedagogy are equally important and necessary to improve 21st century skills (Piffare, 2018). Sujana (2019) asserts that education is a continuous process of activity until the end of life so that it can improve quality human resources. The importance of the learning process so that learning objectives can be achieved. The existence of technology has become increasingly important in learning since the Industrial Revolution 4.0 era and the 2013 Curriculum was applied in the learning process. Teachers are required to be able to develop teaching material based on digital that can be used by students anywhere and anytime (Ramadhani \& Fitri, 2020).

The ability of creativity is one of the abilities needed to face future challenges (Cahyani et al, 2020). Creative thinking skills can be improved through structured programs (Marcos et al, 2020). Innovation makes a solution in improving creative thinking skills (Madden et al, 2013). So that teachers are expected to be able to facilitate students in meaningful learning and can improve students' creative thinking skills. Electronic learning is needed in today's online learning activities.

The demands of teachers to improve future skills in the industrial revolution are very challenging. Teaching using technology as a tool to facilitate learning and improve performance so that learning becomes interactive. The need for the development of teaching materials with the use of technology using the right approach. Development of teaching materials that can facilitate students in the learning process so that the goal can foster students' creative thinking skills.

Teaching materials are tools that can improve student learning outcomes. Presentation of quality teaching materials can make learning meaningful (Wijayanto, 2014). Teaching materials are very important in the learning process (Arnila, 2021). Module is an effective teaching materials in achieving learning objectives. According to Sirate (2017) Modules are teaching materials that are designed systematically. The development of technology and the online learning period of teachers can innovate by being able to present modules in digital format. The ability to think creatively is one of the skills of the 21st century. STEAM is learning what is appropriate to be able to challenge 
the times and move forward dynamically. Development of learning activities covers science, technology, engineering, art and mathematics. STEAM supports the transition of traditional learning to modern learning with the use of digital that can increase student interest in learning. (Milara, 2020). STEAM is needed to improve students' cognitive skills and activities (Thuneberg. 2018). STEAM is very good for education increasing students' understanding of technology and by implementing STEAM education students are able to face future challenges. STEM is a teaching and learning method to develop 21st century skills (Lavi, Tal, Dori, 2021; Eltanahy, et al, 2020). STEM example for advancing engineering education in an international context (Douglas Lecorchick et al, 2020).

In the online learning process, electronic modules are more practical. In accordance with Sugianto (2013), the electronic module is a method of offering self-taught electronic format resources that are organized systematically and include animation, music, and navigation to make users more engaging and meet learning objectives. The usage of e-modules in the learning process is not limited to the classroom; it may also be carried out outside of it. STEM-based e-modules can motivate students to learn independently, are available online, and have a visually appealing display (Arnila et al, 2021). STEM-based e-modules can help students study more creatively (Cahyani, 2020). STEM (science, technology, engineering, and mathematics) integrated learning connects the content taught to the fields of science, technology, engineering, and mathematics (Septiani \& Rustaman, 2017). HOTS learning, which is more focused on problem solving, is prioritized by STEAM. Informal short-term hands-on modules that incorporate the Art of changing STEM into STEAM produce cognitive learning with a significant input from creativity (Thuneberg, 2018). In online learning, visual online posting aids group knowledge and the development of creative abilities (Chaldwell, 2020).

This study aims to find out 1) the feasibility of e-Modules based on STEAM, 2) the importance of e-modules based on STEAM in online learning, 3) Knowing the improvement of creative thinking skills of grade 5 students on the material "My Blood Circulation is Healthy". Teachers can attempt to implement 21st century skills learning by using teaching materials and models that can help students improve their creative thinking skills.

\section{Methods}

This study used a qualitative descriptive study analysis based on literature review, so that it can improve creative thinking and achieve learning objectives optimally. Literature review as a method so that the topic can be comprehensively understood by Cooper (as cited in Perignat (2018). The population in this study were 14 elementary school teachers from 8 sub-districts in Lampung. The initial data collection technique used was Hasanah (2021) questionnaires and questionnaires to teachers and students to obtain useful and important information for pre-research. The sample in the study and the fifth grade students of SDN 2 Rejo Binangun, East Lampung consisted of 16 students.

This study was a development research. The resulting product was an e-module based on STEAM with the material of my blood circulation is healthy. The research model used the model that has been carried out by Marshall, J.C Julie. S \& Robert and Rusdi. The stages in development are problem and needs analysis, literature review, product design, validation, practitioner trials.

Needs analysis in the development of a product is very important to ensure that the product developed is in accordance with user needs. Needs analysis consists of material analysis and literature analysis. Material analysis is used as the basis in the development of electronic modules. In the development of this electronic module, the researcher took the material of My Blood Circulation is Healthy during Learning 1. In taking the material, the researcher analyzed KI, KD and indicators based on the Minister of Education and Culture No. 37 of 2018. Based on the results of the analysis, the researchers provided solutions by conducting further research studies, namely in the form of module development. electronics containing aspects of the demands of KI, KD and material indicators of my healthy blood circulation.

Based on the results of the analysis, the researcher provided a solution by conducting further research studies, namely in the form of developing an electronic module that contained aspects of the demands of KI, KD and indicators in the 2013 curriculum.

\section{Results and discussion}

The result of this development research was an electronic module that created with the material of My Healthy Blood Circulation for learning 1. This study used the STEAM approach of science, technology, engineering, art and mathematics. This study also used the model that has been done by Marshall, J.C Julie, S \& Robert and Rusdi. There are five stages of development, namely problem and needs analysis. analysis of problems and needs, literature review, product design, validity, practitioner trials. However, this development research merely conducted till the validation test stage of the product being developed. The first stage, the researcher conducted needs analysis. The analysis stage was the initial stage in developing this electronic module. The analysis was carried out to identify the facts that exist in the learning process and recommend solutions that were in accordance with the conditions during the initial observation. Needs analysis in the development of a product is very important to 
ensure that the product developed is in accordance with user needs. Needs analysis consisted of material analysis and literature analysis. Material analysis was used as the basis in the development of electronic modules. In the development of this electronic module, the researcher took the material for my healthy blood circulation during learning 1 in class 5 .
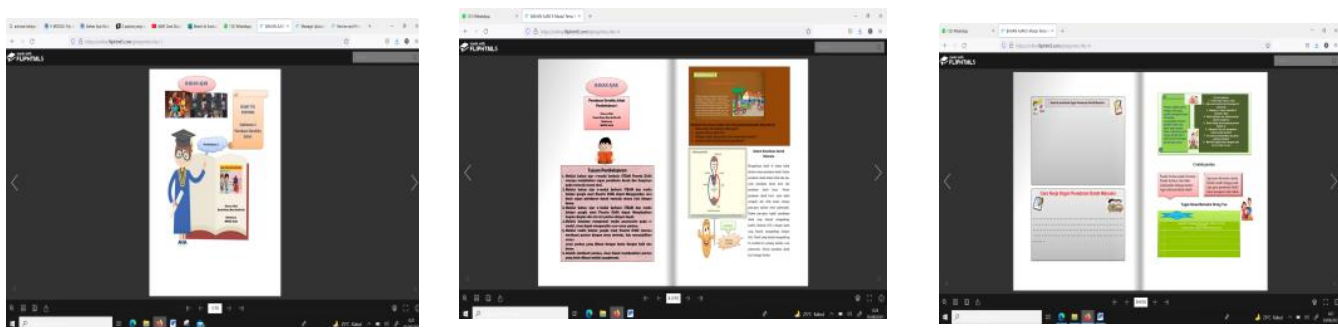

Table 1. Student distribution frequency

\begin{tabular}{lcccc}
\hline No. & Interval & Frequency & \multicolumn{1}{c}{$\%$} & Category \\
\hline 1 & $85-100$ & 59 & $28.36 \%$ & Very Good \\
2 & $75-84$ & 93 & $44.71 \%$ & Good \\
3 & $65-74$ & 37 & $17.78 \%$ & Average \\
4 & $55-65$ & 19 & $9.15 \%$ & Bad \\
& Total & 208 & 100 & \\
\hline
\end{tabular}

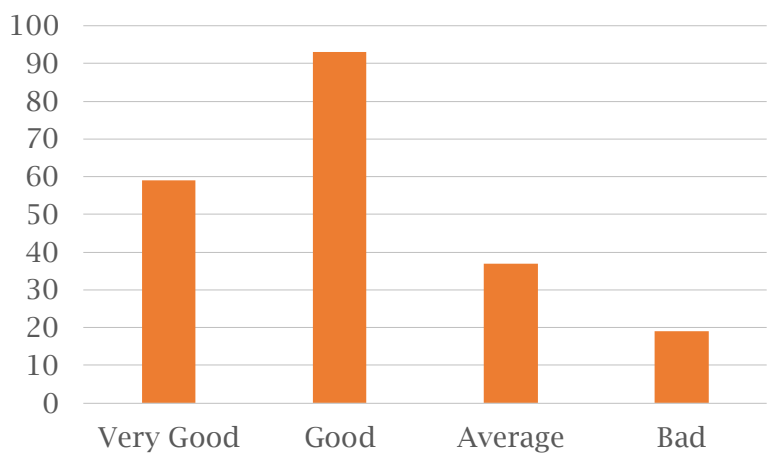

Figure 1. Student distribution frequency

In taking the material, the researcher analyzed KI, KD and indicators based on Permendikbud No. 37 of 2018. Based on the results of the analysis, the researcher has provided a solution by conducting further research studies including in the form of developing an electronic module that contains aspects of the demands of KI, KD and indicators of my healthy blood circulation. search from various sources that can be used as guidelines in designing and developing products. At this stage, the researcher completed a literature review related to research and analyzed relevant research to support the product development process that the researcher developed. The next stage, the researcher designed the electronic module. As for the design form. A display that showed one of the technologies that existed in the e-module After designing the e-module development, the researcher carried out the next stage, namely the development stage.

\section{Conclusion}

Based on the results of the validation and the results of the development of the e-module, it was discovered that the development of an e-module based on STEAM (science, technology, engineering, art, and mathematics) on the material for my healthy blood circulation during learning 1 was successful. The development of the e-module included a pdf format that may be read on a PC or laptop. This e-module was created with videos and a STEM approach, and it can be accessible over the internet.

The e-module development design can be adjusted for additional research by adding experimental simulations utilizing flash. The usefulness of products developed in the form of e-modules based on STEAM (science, technology, engineering, art, and mathematics) on static and dynamic fluid materials utilizing Kvisooft flipbook creator software may be tested in the field. 


\section{References}

Arnila, R. S., \& Purwaningsih, Nehru. (2021). Pengembangan e-modul berbasis STEAM pada materi fluida statis dan fluida dinamis menggunankan kovosft fkipbook maker. Jurnal Pendidikan. 5(1), 551-556.

Buchbinder, O., \& McCrone, S. (2020). Preservice teachers learning to teach proof through classroom implementation: Successes and challenges. Journal of Mathematical Behavior, 58, 100779. https://doi.org/10.1016/j.jmathb.2020.100779

Cahyani, A.E. M., Mayasari, T., \& Sasono, M., (2020). Evektivitas e-modul project based learning berintegrasi STEM (science, technology, engineering and mathematicter) hadap kreativitas siswa. Jurnal Imiah Pendidikan Fisika, 4(1), 15-22.

Caldwel, H., Whewell, E., \& Heaton, R. (2020). The impact of visual posts on creative thinking and knowledge building in an online community of educators. Elsevier Ltd, 1871-1871.

Diani, Rahma., Yanti, Yuli., Hartati Niken Sri. Fujiani, Dwi., Hasanah, Ida Faridatul., \& Alamsyah. (2021). Islamic literacy-based physics e-module with STEM (science, technology, engineering, and mathematics) approach. IOP Publishing Ltd, Journal of Physics: Conference Series, 1796.

Eltanahya, M., Forawia, S., \& Mansour, N. (2020). Incorporating Entrepreneurial Practices into STEM Education: Development of Interdisciplinary E-STEM Model in High School in the United Arab Emirates. Thinking Skills and Creativity, 37. https://doi.org/10.1016/j.tsc.2020.100697

Gelonch, O., Garolera, M., Valls, J., Castellà, G., Varela, O., Rosselló, L., et al. (2018) The effect of depressive symptoms on cognition in patients with fibromyalgia. PLOS ONE, 13(7), e0200057.

Lavi, R., Tal, M., Dori, Y.Z. (2021). Perceptions of STEM alumni and students on developing 21 st century skills through methods of teaching and learning. Elsevier Ltd. https://doi.org/10.1016/j.stueduc.2021.101002

Lecorchick, Douglas., Papadopoulos Joanna., \& Tabor, Lauren. (2020). Engineering education through an international collaboration: a framework. Procedia Computer Science. 172, 838-842.

Sirate, S. F. S., \& Ramadhana, R. (2017). Pengembangan modul pembelajaran berbasis keterampilan literasi. 316-335.

Madden, M. E., et al. (2013). Rethinking STEM education: An interdisciplinary STEAM curriculum, Science Direct. Elsevier B.V.

Milara, I. S., et al. (2020). STEAM in Oulu: Scaffolding the development of a community of practice for local educators around steam and digital fabrication. Teaching and Teacher Education Elsevier B.V, 2212-8689.

Marcos et al, (2020). Promoting children's creative thinking through reading and writing in a cooperative learning classroom. Thinking Skills and Creativity. 36, 100663.

Peraturan Menteri Pendidikan Dan Kebudayaan Republik Indonesia Nomor 37 Tahun 2018. Tentang Perubahan Atas Peraturan Menteri Pendidikan Dan Kebudayaan Nomor 24 Tahun 2016 Tentang Kompetensi Inti Dan Kompetensi Dasar Pelajaran Pada Kurikulum 2013 Pada Pendidikan Dasar Dan Pendidikan Menengah.

Perignat, Elaine., \& Jennifer, Katz-Buonincontro. (2018). From STEM to STEAM: Using brain-compatible strategies to integrate the arts. Arts Education Policy Review, 119(2), 107-110.

Septiani, A., \& Rustaman, N Y. (2017). Implementation of Performance Assessment in STEM (Science, Technology, Engineering, Mathematics) Education to Detect Science Process Skill To cite this article. J. Phys.: Conf. Ser. 812012052.

Sugianto, Heri. (2013). Penerapan model kontektual berbantuan multimedia untuk meningkatkan penguasaan konsep dan literasi sains siswa pada materi fluida di SMA kelas IX IPA. Jurnal Penelitian Pendidikan. 12(1), 1-7.

Sujana, I Wayan Cong. (2019). Fungsi dan tujuan pendidikan indonesia. DI WIDYA: Jurnal Pendidikan Dasar. 4(1). ISSN: $2527-5445$.

Thuneberg, H.M., et al. (2018). How creativity, autonomy and visual reasoning contribute to cognitive learning in a STEAM hands-on inquiry-based math module. Elsevier Ltd, 1871-1871.

Wijayanto, Muhammad Saifuddin Zuhri. (2014). Pengembangan e-modul berbasis flip book maker dengan model project based learning untuk mengembangkan kemampuan pemecahan masalah matematika. ISBN: 978-602-0960-00-5. 